
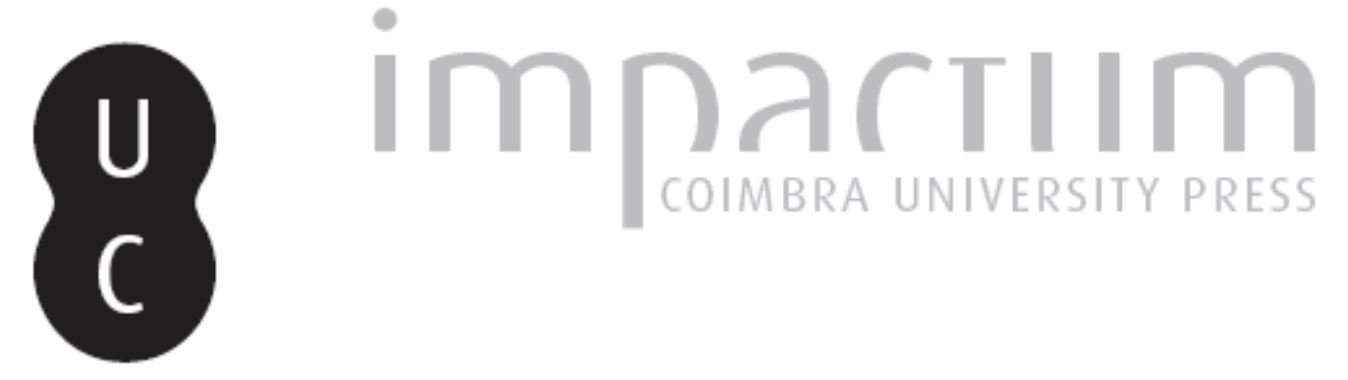

\title{
É a Faculdade e não o Conselho Geral, estúpido!
}
Autor(es): Bento, Jorge Olímpio
Publicado por: Fórum de Gestão do Ensino Superior nos Países e Regiões de Língua Portuguesa

URL

persistente:

URI:http://hdl.handle.net/10316.2/36217

DOI:

DOI:http://dx.doi.org/10.14195/2183-2722_1-1_2

Accessed : $\quad$ 26-Apr-2023 11:25:52

A navegação consulta e descarregamento dos títulos inseridos nas Bibliotecas Digitais UC Digitalis, UC Pombalina e UC Impactum, pressupõem a aceitação plena e sem reservas dos Termos e Condições de Uso destas Bibliotecas Digitais, disponíveis em https://digitalis.uc.pt/pt-pt/termos.

Conforme exposto nos referidos Termos e Condições de Uso, o descarregamento de títulos de acesso restrito requer uma licença válida de autorização devendo o utilizador aceder ao(s) documento(s) a partir de um endereço de IP da instituição detentora da supramencionada licença.

Ao utilizador é apenas permitido o descarregamento para uso pessoal, pelo que o emprego do(s) título(s) descarregado(s) para outro fim, designadamente comercial, carece de autorização do respetivo autor ou editor da obra.

Na medida em que todas as obras da UC Digitalis se encontram protegidas pelo Código do Direito de Autor e Direitos Conexos e demais legislação aplicável, toda a cópia, parcial ou total, deste documento, nos casos em que é legalmente admitida, deverá conter ou fazer-se acompanhar por este aviso. 


\section{REVISTA}
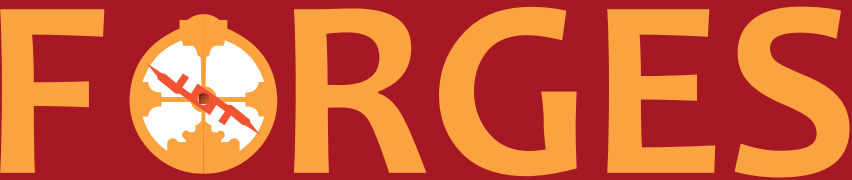

Fórum da Gestão do Ensino Superior nos Países e Regiões de Língua Portuguesa

Ensino Superior

Organizadores

Sônia Fonseca | Luísa Cerdeira |

Tomás Patrocínio
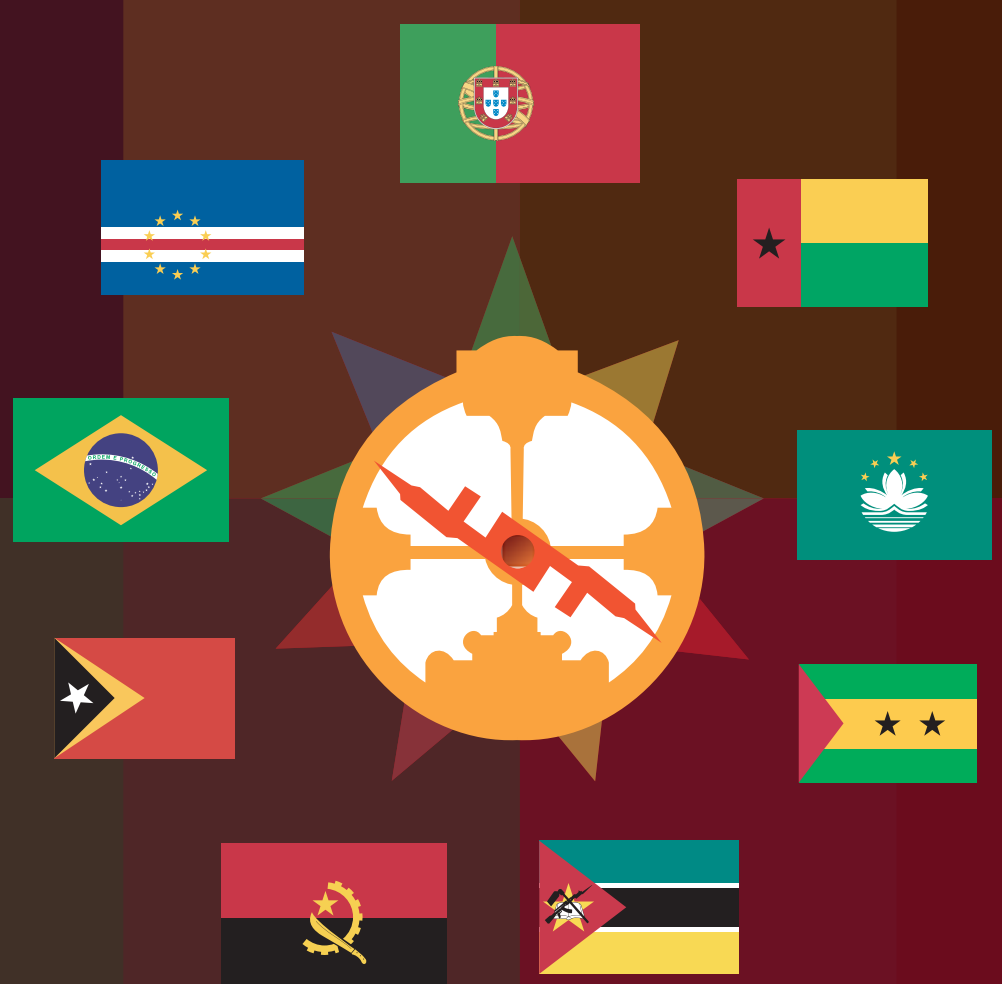


\section{2 \\ É a Faculdade e não o Conselho Geral, estúpido!'}

Jorge Olímpio Bento ${ }^{2}$

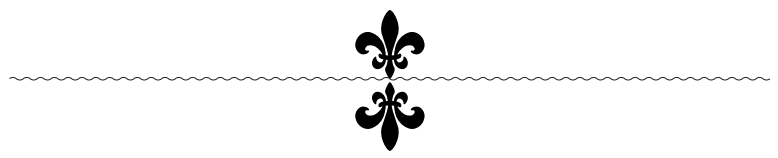

0 milagre não é voar pelos céus ou andar sobre a água, mas andar na terra.

Provérbio chinês

\section{Ao jeito de introdução}

O leitor percebeu certamente, no título deste ensaio, três coisas:

Primeiro: Ele inspira-se na proclamação (It's the Faculty, stupid!) que Philip Alltbach, respaldado em Bill Clinton (It's the economy, stupid!), lançou em 2009 aos docentes das universidades de todo o mundo, convidando-os a pugnar pela centralidade da função docente na instituição académica e a não aceitar a ignóbil canga dos managerialistas e dos stakeholders externos. ${ }^{3}$

Segundo: As considerações, expressas no texto, visam enfrentar o medo (ai, quantos medos, com razão ou sem ela, andam por aí à solta a atarantar as pessoas e a sua vida!) de questionar a existência

1 As ideias fulcrais, que sustentam este ensaio, podem ser procuradas in: Jorge Olímpio Bento, Por uma UniverCidade anticonformista. Universidade do Porto: Editora FADEUP, julho de 2014.

2 Professor Catedrático e Diretor da Faculdade de Desporto da Universidade do Porto.

3 Philip G. Altbach, It's the faculty, stupid!, Times Higher Education, 30 de abril de 2009. (Philip G. Altbach é professor universitário e diretor do Centro Internacional para Educação Superior, Boston College, EUA). 
do Conselho Geral nas universidades públicas portuguesas e as finalidades e motivações políticas e ideológicas que presidiram à criação deste órgão e o impuseram brutalmente à comunidade académica, com a inaceitável conivência e cumplicidade de não poucos reitores.

Terceiro: Ora eu não quero incorrer no pecado cívico, acabado de referir. Seja porque a educação, iniciada no berço familiar e prolongada no trajeto escolar e existencial, me obriga a trilhar outros caminhos. Seja porque tenho em alta conta e sinto a gravidade da advertência do Padre António Vieira (1608-1697): "Pelo que fizeram, se hão-de condenar muitos, pelo que não fizeram, todos." $\mathrm{E}$ a de Vitor Hugo (1802-1885): "A traição trai o traidor." Sem olvidar a do poeta latino Ovídio (43 a.C.-17 ou 18 d.C.): "Se formos cobardes e não tivermos coragem para enfrentar as tempestades, acabaremos a rastejar."

Creio que, destarte, está dado o mote para o que vem em seguida. Para não faltar ao encontro e compromisso com a verdade que tanto nos falta e tanta falta nos faz.

Resta acrescentar que o presente testemunho é fundado na experiência registada pelo seu autor no enfrentamento da governança adotada e praticada pela Universidade do Porto nos últimos 7-8 anos. É o testemunho de quem se bateu contra o RJIES - Regime Jurídico das Instituições de Ensino Superior, mal a sua proposta foi publicamente divulgada. É a voz dorida de um vaticínio que se consumou numa modalidade ainda pior do que a anunciada.

\section{RJIES - uma engenharia antidemocrática, burocrática e destrutiva}

1. A Modernidade legou-nos a Democracia, a ética e os valores republicanos. A 'Pós-Modernidade' está a impor-nos a pósdemocracia ou cleptocracia, a captura, o roubo, o couto privado, a instrumentalização e manipulação dos poderes do Estado por lóbis e oligarquias.

Tudo sugere que a democracia traiu a sua inspiração original: desistiu de ser uma forma evoluída da ágora, o lugar do encontro, da conversa, da congregação das pessoas e das suas ideias e opiniões. A memória dessa ágora esfumou-se; e o grau da conciliação, 
coordenação e da mediação da esfera privada (oikos) e da pública (ecclesia), verdadeira medida padrão da saúde suficiente de uma democracia, conhece o fracasso, pondo a nu o estado de torpor da versão democrática em vigor.

O apoderamento da democracia por instituições visíveis (FMI e Banco Central Europeu, entre outras) e invisíveis (mercados globais, organizações secretas etc.) ocasiona que ela esteja caminhando ufanamente na direção oposta ao da ágora. O sentido de comunidade ou sociedade real ou imaginada ausentou-se para parte incerta. A ágora ou já não existe ou nada convida as pessoas a tomar conta da sua existência e a visitá-la. De uma maneira ou de outra, ela recebeu a certidão de óbito, passada pelo deus 'mercado'. ${ }^{4}$

Observemos com acuidade o que se passa nesta deriva da democracia. Também aí, a luta permanente entre a pulsão de vida (também chamada de eros, aquela que agrega, que nos assegura a unidade do ser e nos faz procurar o outro para construi uma humanidade fraterna e radiosa) e a pulsão de morte (thánatos, a que separa o que não serve mais para continuar unido) está a ser ganha pela última.

Reconheçamos que estamos no pleno regime da pulsão de morte, a viver o momento de destruição de um projeto de democracia e humanidade que fracassou. Que perdemos a ligação ao outro, que este não existe na atenção 'democrática' vigente e que caímos nas garras de uma individualidade inútil e destrutiva. Reconheçamos este fracasso e assumamos o compromisso de o abandonar e de tentar construir, a partir dos seus escombros, um novo projeto de ágora e da sua representação e tradução noutra forma de democracia.

Zygmunt Bauman constata: "Uma das chagas mais evidentes dos regimes democráticos é a contradição entre a universalidade formal dos direitos (...) e a capacidade nem tão universal de seus portadores de exercer de fato esses direitos; em outras palavras, a brecha entre a condição jurídica de um 'cidadão de jure' e a capacidade prática de um cidadão de facto ..."

A democracia está em risco. Vivemos uma era 'liberticida' ou de 'fadiga da liberdade' ou de suspensão da liberdade, expressa na aparente "placidez com que a maioria de nós aceita o processo de limitação gradual de nossas liberdades tão difíceis de conquistar..."

4 Zygmunt Bauman, Danos Colaterais - Desigualdades sociais numa era global, p. 17-26. Rio de Janeiro: Jorge Zahar Editor, 2011. 
"Num mundo tão inseguro como o nosso, a liberdade pessoal de palavra e de ação (...), de acesso à verdade - todas essas coisas que costumávamos associar à democracia e em nome das quais ainda fazemos guerra - precisam ser reduzidas ou suspensas. Ou pelo menos é o que declara a versão oficial, confirmada pela prática." 5

Não apenas os direitos fundamentais das pessoas estão sendo suprimidos, um a um; é a própria democracia que é alvo de ardilosa desmontagem, peça a peça. Esta 'evolução' é particularmente visível em Portugal; foi igualmente instalada na Universidade, por obra e graça do RJIES - Regime Jurídico das Instituições de Ensino Superior.

2. A Universidade pública portuguesa está a funcionar segundo 'valores' muito distantes e até antagónicos em relação aos que presidiram à criação da Universidade Moderna - e ainda hoje, quando convém aos detentores do mando, são afirmados com pompa e circunstância, porém sem correspondência na sua orientação atual. Mais grave ainda, também nela encontram sagração práticas autoritárias do poder, de supressão da democracia e de esquecimento da consideração condigna e decente devida aos seus membros. $\mathrm{Na}$ Universidade pública assentou arraiais um discurso ou palavreio oficial, obsessiva e ostensivamente 'empresarial', que nunca nomeia os trabalhadores e as suas prerrogativas sociais, nem o melhorismo da vida dos cidadãos como objetivo cimeiro de uma política voltada para o bem comum.

Não olvidemos que a identidade de um povo ou de uma organização (como, p. ex., a Universidade) forja-se na defesa da dignidade e do respeito, do seu ser e do ser dos outros que são diferentes.

Ora, ao aceitar o Conselho Geral e outras imposições e determinações do RJIES, bem como os linguajares que as reproduzem, concretizam e ampliam, a Universidade pública subtrai-se à defesa da sua dignidade e respeito; abdica de cumprir um papel de inspiradora referência e exemplaridade e entrega-se à vil genuflexão, subserviência e conúbio com entidades que ignoram o mandamento do trato humano. ${ }^{6}$

5 Zygmunt Bauman, ibidem, p. 20-30.

6 No caso da U. Porto, a adoção do regime fundacional levou a acrescentar mais um órgão tutelar à cadeia de burocratização e perda de autonomia e independência: o Conselho de Curadores. 
Concomitantemente fica incapaz de se afirmar como contraponto ao clima de suspeição que hoje marca o relacionamento dos cidadãos com o poder político, rompe o contrato de confiança com a sociedade e a democracia. Ou seja, perde condições para avocar a defesa e promoção da ética da dignidade e do respeito dos outros; logo, torna-se uma instituição humana e socialmente dispensável e descartável.

Modelada pelo reformismo do RJIES, a Universidade pública aposentou a metáfora do organismo vivo e trocou-a pelo modelo arcaico e obsoleto da fabricação taylorista. Não é mais o sujeito utopista e proponente de modos de mudança num mundo complexo e incerto; esse impulso e capacidade foram subjugados pela dependência das forças da homogeneização e uniformização. À luz das lições de Darwin, este acomodamento é prenúncio de morte e não de vida.

Hoje, seja dentro dos muros da cidade, seja dentro dos da universidade, somos forçados ao ultraje de viver como se fôssemos livres. Na realidade somos tratados como servos da gleba. Por outras palavras, vivemos num tempo de servidão mais ou menos mitigada. Para alguns esta é voluntária, por conveniência, oportunismo ou amancebamento com a falta de coragem e dignidade de a abjurar e rejeitar; para a maior parte é imposta pela infinita panóplia de mistificações oficial ou oficiosamente postas em circulação.

Como é sabido, a mistificação consiste em fazer alguém acreditar em mentiras, dando a estas o cariz de verdades incontestáveis. Exponhamos alguns exemplos de descaradas mistificações:

Afirmar que vivemos em democracia ou em república;

Apregoar que Portugal teve uma 'saída limpa' do programa de austeridade ditado pela troika e afetuosamente abraçado pelo (des)governo do nosso país;

Acreditar que o nosso governo é patriótico e cuida da soberania nacional; ${ }^{7}$

Sustentar que a eleição do Reitor pelo Conselho Geral é feita exclusivamente em função dos méritos dos candidatos, comprovados nas peças e provas exigidas no edital de candidatura; que todos os eleitores (conselheiros)

7 A este propósito recomenda-se a leitura do texto "A direita deixou de ser patriótica (1)", da autoria de José Pacheco Pereira. Jornal Público, p. 52, 05.07.2014. 
as leem e presenciam consciente e objetivamente e votam na escrupulosa observância do conteúdo das mesmas, libertos de quaisquer influências e pressões. ${ }^{8}$

3. Este défice democrático traz-nos à lembrança a obrigação proclamada por Péricles (cerca de 495/492-429 a.C.), o fundador da democracia ateniense: "Diferenciamo-nos de outros Estados por considerar inútil o homem que fica alheio à vida pública."

O lembrete de Péricles acorda em nós o vício incorrigível da democracia e autonomia, da participação empenhada e volitiva na Cidadania Universitária. Por razões éticas e também funcionais: porque assim nos abeiramos da matriz do nosso ser e das nossas obrigações cívicas e também porque, onde imperam a desconfiança e a estranheza, não são possíveis a interação e o funcionamento harmonioso e advém a desagregação.

Perante isto, quais são a função e a responsabilidade dos académicos e intelectuais na construção e difusão de uma moral incondicional, acima das peias das circunstâncias e dos interesses dominantes? Estão a ser devida e inequivocamente exercidas?

Os universitários e os intelectuais têm o dever de falar e intervir, de assumir o lema de uma pessoa livre: não vender a alma a nenhum bem deste mundo. Estão obrigados a envolver-se com a anulação de um destino decretado como inevitável. Pertencem ao 'partido do contra' o statu quo, no dizer de Pierre Bourdieu (1930-2002). Incumbe-lhes ser

8 Por exemplo, no edital da candidatura da eleição do Reitor da Universidade do Porto, realizada em 30.04.2014, afirmava-se taxativamente: "O candidato a reitor deve:

1. Ser uma personalidade de reconhecido mérito e com experiência profissional relevante para as funções a exercer;

2. Possuir visão estratégica adequada à prossecução da missão e fins da Universidade do Porto, nos termos dos respetivos estatutos;

3. Ter demonstrada capacidade de promotor de valores humanísticos e científicos num ambiente de colegialidade e inclusão."

Os candidatos apresentaram um programa de ação e o curriculum vitae, e foram sujeitos a uma audição pública pelo Conselho Geral, tendo os elementos deste colocado as questões que tiveram por bem. Apesar do cenário de tipo concursal, a escolha do Reitor foi feita por escrutínio secreto, sem fundamentação das votações. 
demiurgos, portadores de atitudes e palavras luminosas e mercuriais, criadoras de circunstâncias equivalentes. São 'ajudadores' situados perto das fontes de incerteza, vinculam-se ao ofício de as procurar esclarecer ou iluminar. Por sua vez, Zygmunt Bauman coloca-lhes o carimbo de 'legisladores e intérpretes': responsáveis pela formulação de normas ou, pelo menos, de interpretações da realidade.

Detêm, portanto, um poder de tipo 'pastoral' (pasto, pastor, pastoreio e sustento), segundo Michel Foucault (1926-1984), em benefício dos outros, recorrentes aos serviços de conhecimento.

Em síntese, assumem uma responsabilidade social e humana, que é a de não fazer de Mefistófeles (Fausto, Goethe; Doutor Fausto, Thomas Mann), ou seja, de não traírem a sua missão, a si e aos outros.

Assim devia ser. Só que a história, nomeadamente a recente, está cheia de traições dos intelectuais (e dos académicos!). A atualidade é perfeita para eles se redimirem de um passado não honroso. Não se podem calar, nem fazer de conta que não veem, mesmo que o estado da coragem não seja pletórico de energia, porque, alertou Santo Agostinho (354-430), "é melhor andar mancando pelo caminho do que correr fora dele."

4. Foi deste jeito que, em 22 de junho de 2007, tomámos posição inequívoca acerca da Proposta de Lei do Regime Jurídico das Instituições de Ensino Superior, que o Ministro da tutela submeteu a uma muito fugaz e sorrateira discussão, pouco ou nada refletida e pública, numa ambiência cuidadosamente familiar e quase sigilosa.

O panorama hodierno apresenta-se adequado para abrir a arca das memórias e tirar cá para fora alguns dos comentários que, na altura, nos pareceram avisados e oportunos. O decurso do tempo incumbiu-se de reforçar os receios que então nos assistiam. Não se tratou de profecia, nem tampouco de ato corajoso, mas tão-somente de cumprir o dever cívico de tomar a palavra e usar as palavras para referir aquilo que estava à vista de todos os que quisessem parar e olhar o andamento de um comboio que se preparava para decapitar a Universidade pública. Passamos a transcrevê-los, tal como foram formulados na ocasião.

\section{Primeiro:}

A extensão do texto do RJIES é justificável pela circunstância de a lei em causa não visar propriamente uma reforma (melhoria) 
do regime existente. A proposta visa, sim, pôr termo a um entendimento da Universidade, da sua idiossincrasia e do respetivo modelo de organização. Ou seja, há nela algo que agora chega ao fim e é posto de lado.

\section{Segundo:}

Na proposta de lei estão bem expressos os 'princípios' e 'valores' que hoje prevalecem numa conjuntura de condicionamento da política pelo mercado. Uma valorização datada e situada de alguns vetores da economia e gestão sobrepõe-se às restantes dimensões, relegando-as para um lugar inferior e até para o esquecimento. Neste ponto, a proposta tem o mérito de ser clara, lógica e coerente.

\section{Terceiro:}

A nomeação do Reitor por um Conselho Geral expressa bem a matriz conceptual que perpassa a proposta de lei.

Este processo tem certamente vantagens, à luz exclusiva dos focos da economia e gestão em moda. Todavia, encerra desvantagens e perigos que não podem ser ignorados. Ao decorrer muito distante da comunidade académica, favorece o divórcio e alheamento desta em relação a um assunto que devia merecer a sua melhor atenção e interesse.

Acresce que o Reitor não é mais responsável perante a Universidade, mas apenas efetivamente perante o Conselho Geral, vendo por isso - que estranho paradoxo! - o seu poder diminuído, fragilizado e condicionado por tal órgão, sem poder contar com o respaldo e a cumplicidade da comunidade académica.

A tradicional eleição do Reitor por um colégio eleitoral representativo da diversidade do corpo universitário conferia-lhe mais legitimidade, apreço e sintonia junto deste. Ao invés, a proposta de lei torna o Reitor estranho à comunidade académica; consagra a supremacia do Conselho Geral e a subalternidade e dependência do Reitor.

\section{Quarto:}

Há outra dúvida que a criação do Conselho Geral, a sua mais que provável composição e o processo de escolha do Reitor legitimam inteiramente. Tudo aponta para que doravante as Faculdades 
não tenham todas as mesmas possibilidades, nem reais nem formais, de assegurar a sua representatividade institucional nos órgãos da Universidade. Aquilo que vigorou até ao presente vai cessar de maneira inexorável.

O ambiente de exaltação e veneração da tecnologia e das bitolas económico-financeiras, tão enfatizado e triunfante nos dias de hoje e transposto para a Universidade pela lei em apreço, é altamente propício a gerar filhos e enteados, a favorecer os fortes e poderosos e a desconsiderar os restantes.

Dito de outro modo, as Faculdades não vão continuar a ter o peso que agora ostentam, nem vão contar com a mesma consideração; natural e funcionalmente as hierarquias vão impor-se da forma mais dura e crua. As tentações e manifestações de hegemonia têm terreno fértil para medrar.

Tudo isto significa que fica criado o perigo real de se estabelecer um clima de desconfianças, divisões, afrontamentos e suspeições e que a Universidade pode vir a confrontar-se, a breve trecho, com tendências, atitudes e factos de quebra de unidade, de fraturas e desagregações, de cisões e coisas afins.

\section{Quinto:}

Poderá retorquir-se que não há razões para temores, porquanto este modelo conhece sucesso noutras paragens. Porém, um modelo não pode abstrair do seu ambiente original e natural e ser transplantado, sem as necessárias adaptações, para um contexto cultural e socialmente muito diferente.

Saliente-se ainda que a atuação do governo no tocante à implementação do Processo de Bolonha e a justa preocupação em relação à legislação que está para vir não diluem as dúvidas, nem inspiram confiança.

5. Repete-se, as considerações atrás expostas são transcritas do documento enviado ao Magnífico Reitor da Universidade do Porto, em 22 de junho de 2007. De então para cá confirmou-se que não eram infundadas a perceção e a sinalização dos descaminhos que elas denunciavam. Bem pelo contrário.

Digamo-lo, sem quaisquer floreados ou rodeios de linguagem: o RJIES é produto de uma engenharia antidemocrática, burocrática e 
destrutiva. Autojustifica-se como uma autocracia e tecnocracia de 'sábios' e soberanos absolutistas, que outorgam a si mesmos o privilégio 'natural' de ostracizar os 'peões de brega' que não sabem das lides gestionárias e são apenas ruído perturbador do bom e mercadológico desempenho da gestão universitária.

O RJIES, além de colocar a Universidade pública portuguesa no colo da ideologia neoliberal, das respetivas orientações e receitas, criou as condições para o curso do absolutismo, autoritarismo, centralismo e voluntarismo iluminados; e elas foram, aqui e ali, aproveitadas para cortar ou reduzir à expressão mínima a dimensão daquilo que é fundamental na democracia.

Mais ainda, as putativas (que termo tão estranho, porém inteiramente ajustado!) 'reformas', impostas ao povo português pela gélida crueldade da gadanha e seitoura mercadológicas, adentraram a Universidade, contando com o apoio entusiástico de vários Reitores, alguns mais, outros menos, gratificados com a figura de capatazes. Esta acusação atinge intencionalmente o CRUP - Conselho de Reitores das Universidades Portuguesas, que se transformou numa ortodoxia do autismo, muito semelhante ao diretório da União Europeia. Está na hora de requerer aposentadoria, porquanto fala em nome das Universidades, conferindo foral de genuína representatividade à opinião de Reitores não eleitos por elas, mas escolhidos por Conselhos Gerais que estão longe de representar a comunidade académica.

Não é verdade que o RJIES está inquinado de uma visão ideológica, louvaminhada por vários poderes e interesses, que retira autonomia à Universidade, tem em baixo conceito os académicos e coloca ela e eles sob uma tutoria alheia?

(A confraria do mercado e dos negócios montou e sustenta um coro da 'eficácia', do 'empreendedorismo' e 'produtivismo', do 'economês', 'financês' e 'utilitês', que integra solistas avençados e esganiçados nos media e conta como apoiantes administradores universitários e os seus amos governamentais. Todos se exibem muito sintonizados a cantar a ladainha de que o professorado é a raiz de uma pretensa ineficiência da universidade e de que, por conseguinte, ele precisa de ser tutelado por representantes de entidades externas. Escamoteiam relevantes estudos internacionais demonstrativos de que a gestão privada não é mais eficiente do que a gestão pública e de que a 
privatização de serviços públicos conduz a uma baixa da qualidade.

Estes propagandistas não se cansam de impingir como produto louvável a situação a que chegamos: vivemos o desalento, o desencanto e a insatisfação perante um mundo e uma universidade que já não oferecem nada; só vendem.)

Não é verdade que os Reitores eleitos ao abrigo do RJIES têm falta de legitimidade democrática, não podem exibir a garantia de representar a vontade maioritária da academia e alguns deles muito provavelmente não estariam investidos no cargo, se a eleição fosse incumbência de um colégio genuinamente representativo da comunidade académica? Há algum exagero nesta acusação?

É falso o posicionamento de que alguns dos omnipotentes Conselhos Gerais, impostos pelo RJIES, em vez de serem órgãos ocupados em zelar pela orientação, coesão e mobilização da Universidade, têm sido instrumentos de fratura, de instabilidade e tensão? Quem quiser, faça o favor de proceder a um desmentido! Mas antes dê-se ao cuidado de realizar um estudo sobre o real alcance do contributo dado às instituições de ensino superior pelos Conselhos Gerais, nos anos que levam de funcionamento.

Com o RJIES, a Universidade perdeu autonomia e independência face aos poderes e às corporações de interesses, abdicou de uma parcela assaz significativa da sua missão perante a sociedade, reduzindo esta à dimensão do mundo das empresas e negócios. Caiu no controlo de forças que não controla.

Ademais, pode chegar-se a um ponto em que venha a confirmarse, mais uma vez, o ditado popular: O feitiço vira-se contra o feiticeiro. O que é que isto quer dizer?

Quer dizer muito simplesmente o seguinte: a incontida volúpia de destruir a solidez da organização tradicional da Universidade, de esvaziar de competências e marginalizar as Faculdades e os seus órgãos, levou a centralizar o poder numa cúpula formada pelo Conselho Geral e pelo Reitor, a atribuir ao primeiro responsabilidades superiores às do segundo e a tornar este um mero executor das ordens dimanadas daquele.

Esta interpretação não é fruto da imaginação; ela estriba-se numa ponderação atenta das atribuições que se encontram expressamente exaradas em normativos legais. Se o Conselho Geral reivindicar o exercício efetivo dos poderes que lhe estão consignados, ao 
Reitor restará desempenhar um papel de ridícula secundarização: a de mero cabo de ordens!

Em síntese, o RJIES dá indisfarçada guarida a um sistema ideológico e coercivo sobre a Universidade, redigido por alinhamentos com visões radicais de economia e de gestão empresarial. Perante isto, apelamos à comunidade académica para que se erga com o propósito de obviar os excessos de controlo e os défices de representação democrática de que o dito regime enferma a olhos vistos; e seja porta-voz, junto do ministério da tutela, da necessidade de modificação do RJIES. Mobilizemo-nos e exijamos a sua inadiável revisão!

\section{Erosão da representatividade}

1.Este problema insere-se no vórtice da crise do país e da Universidade.

A erosão da representatividade dos cidadãos pelas instituições políticas (Assembleia e Presidência da República, Governo e partidos políticos), que supostamente a deviam assegurar, é hoje um dado incontestado. Promessas eleitorais não cumpridas, adoção de políticas não sufragadas em eleições, propaganda enganosa, anestesia, desprezo, condicionamento e manipulação das consciências - tudo isto ajuda a compor o retrato de um povo abandonado à sua sorte, obrigado a gerir, por sua conta e risco, a angústia e insegurança do presente, a desconfiança e receio do futuro.

Idêntica erosão encontra-se na Universidade. Os anos da gestão sob a vigência do RJIES e do Conselho Geral, goste-se ou não de ouvir ou ler isto, foram marcados pela ascensão de posições antidemocráticas. Há criaturas convencidas de que, por terem sido eleitas ou escolhidas (por órgãos de insuficiente representatividade), gozam, para implementar o seu plano estratégico, da 'faculdade', do poder ou livre arbítrio de tomar as medidas que entenderem, mesmo que sejam de duvidosa legalidade à luz do Estado de Direito e atropelem os princípios que um indivíduo complicado e desassossegador, chamado Kant, nomeou 'imperativos morais'.

Sentem-se 'chefes' e ignoram que o essencial da democracia é 
o voto e a lei; e que não basta o voto, nem só a lei, há algo mais a respeitar. A democracia não é uma formalidade; é uma prática com materialidade. Cuidam que a governação pode ser feita, segundo os apetites, os interesses, as ideologias e as preferências pessoais, sem qualquer peia cultural, civilizacional, ética, legal e social, sem entraves, ou seja, de forma antidemocrática e pouco 'universitária'. E não têm qualquer rebuço em implementar medidas, recorrendo à contagem de espingardas.

Este cenário ordena que se declare em alto e bom som: o método de governo arrogante e impositivo não é curial e digno da Universidade; esta exige outro mais humilde, mais dialogal, mais transparente, que procure o consenso e respeite a liberdade e a votação em todos os níveis da estrutura.

Mais, por força de um RJIES urdido objetivamente em função das lógicas e dos interesses de controlo, orientação e poder de determinados grupos, acrescendo as modalidades de implementação casuística do dito regime, a representatividade dos atores da Universidade pelos órgãos de cúpula está deveras debilitada. $\mathrm{O}$ alheamento da maioria em relação aos assuntos fulcrais é a consequência inevitável e manifesta; seria extremamente grave e deplorável que ele corresponda a um 'dano colateral' ansiosa e intencionalmente arquitetado e almejado.

Sustentar que não há condições para modificar a situação e que ela deve continuar como está, equivale a querer tapar o sol com a peneira!

Em verdade, o Reitor, eleito por um Conselho Geral com a composição do atual, não é democraticamente Magnífico; apresenta carências de legitimação e de representação democráticas da Universidade e vê-se colocado numa posição de debilidade, de estranheza e exterioridade em relação a ela. Com efeito, ele é escolhido por um colégio deveras escasso, que não contém representantes da maior parte das Faculdades. Além disso, é bem provável que a maioria, ou pelo menos um número muito significativo de membros da comunidade universitária não conheça sequer o seu nome.

Este modelo de eleição e de composição do Conselho Geral é mal copiado e importado de um quadrante pautado por uma ética protestante, dissemelhante do que acontece num país latino, como é o caso do nosso. Lá, qualquer candidato a Reitor, que se abeirasse de 
um membro do Conselho Geral solicitando o seu voto, seria imediatamente excluído da eleição. Entre nós não é assim: um órgão desta natureza funciona em circuito fechado e é passível de ser propenso ao tráfico de influências; a probabilidade de isto suceder é tanto maior quanto menor for o número de integrantes do organismo. Por isso, se ele for para manter e houver uma genuína vontade de que cumpra a função eleitoral acima da suspeita, então o número dos seus membros tem que ser significativamente aumentado.

Quanto aos cooptados, eles têm que ser conhecedores das circunstâncias e problemas da Universidade, das ansiedades e sensibilidades da comunidade académica; estar à altura da correspondência solicitada e não ser portadores de mais nenhuma incumbência. A cooptação deverá ater-se às provas dadas neste capítulo.

Estiquemos a corda até onde ela permite, tendo bem presente este dito sobejamente conhecido, inteiramente aplicável ao que sorrateiramente se vai entranhando na Universidade a ponto de chegar o dia em que já não se estranha: Quem adormece na democracia, acorda na ditadura!

Nas provas e concursos académicos não há votações secretas; os votos são assinados e fundamentados. Ao ser introduzido no perímetro universitário, o Conselho Geral devia estar vinculado a um normativo idêntico em atos como os de examinar e votar os documentos e prestações elencados no edital da candidatura a Reitor. Lá isso devia! Porém, o legislador 'distraiu-se'; só assim, por dormente distração, se compreende que ele não tenha contemplado aquela tão salutar norma de procedimento.

Não se venha contrapor, alegando que, por regra geral, a eleição dispensa a justificação do voto. A colocação de palas legalistas nos olhos não colhe, não tem cabimento aqui; escusam de a ostentar. E porquê? A escolha do Reitor reveste, no atual figurino processual, outros contornos. Ela apresenta-se como um concurso formal, sendo o resultado apurado com base na apreciação dos requisitos exigidos aos candidatos e das provas por eles prestadas. Os requisitos e as provas, repete-se, são tornados públicos mediante um edital. Mais, a audição dos candidatos é aberta à presença da comunidade, e inclui perguntas e respostas. Coerentemente esta opereta não pode ser 'só para inglês ver' ou para 'jogar ao faz de conta'!

Isto, sim, requer melhoria 'reformista', para obstar liminarmente 
qualquer suspeição. Ou será que é defensável dispensar o Conselho Geral da demonstração explícita, inequívoca e convincente de idoneidade e transparência num processo de tamanha relevância para a Universidade? Alguém tem medo dela? Não terá aplicação aqui o conhecido aforisma "à mulher de César não basta sê-lo; é preciso parecê-lo"? ${ }^{9}$

A eleição do Reitor era muito bem concebida e conseguida pela assembleia eleitoral, genuinamente representativa dos corpos da Universidade, que o RJIES abateu e substituiu pelo Conselho Geral. Entregue a este órgão, a eleição é um ato híbrido; é uma mescla de escolha e nomeação. Acresce que, não sendo eleito, nem avalizado e avaliado pela comunidade académica, ele não responde perante esta, mas apenas perante o Conselho Geral.

2. A entrega de poderes de direção e da eleição do Reitor ao Conselho Geral constitui uma afronta grosseira e ultrajante da Universidade, atentatória da honorabilidade dos seus membros, em especial dos docentes. O CRUP e os seus Reitores erguem amiúde a voz, sob o pretexto da restrição da autonomia pelo governo, dizendo que ela é pedra basilar da boa administração universitária. Estranhamente nunca a levantaram contra o roubo da parte mais simbólica e substancial da autonomia da Universidade. Talvez por não terem lido Pierre Bourdieu: “O poder simbólico é esse poder invisível, o qual só pode ser exercido com a cumplicidade daqueles que não querem saber que lhe estão sujeitos ou mesmo que o exercem. Poder quase mágico, que permite obter o equivalente daquilo que é obtido pela força (física ou económica), só se exerce se for reconhecido, quer dizer, ignorado como arbitrário."10

Quão triste é ver uma instituição, que devia ser casa do espírito livre e vigilante, colonizada e comandada por outras ordens de interesses! Quão antidemocrático é ter um Reitor eleito pelos votos de quem não pertence à Universidade e dos que nela são precários e passam a correr em direção à tão almejada e compensadora carreira

9 Não se confunda o meu posicionamento com falta de 'respeito' a um órgão como é o Conselho Geral. Está na moda invocar o 'respeito' das instituições como um método de imposição do statu quo e das limitações de liberdade, assim como de perpetuação de abusos e privilégios inaceitáveis.

10 Pierre Bourdieu, Memória e Sociedade. Lisboa: Difel, 1994. 
política, quando a maioria dos seus membros, se lhe fosse permitido, faria outra escolha!

Não se contesta a existência de um Conselho Geral. Mas... com outro cariz, sem aquela função eleitoral e sem incumbências governativas! Seria um órgão de congraçamento da Universidade com o país, a cidade e a região, de composição algo diferente da atual, embora incluindo personalidades do entorno cultural e social, tal como se regista no ordenamento vigente.

Com a sua intermediação, a Universidade avivaria o relacionamento com o contexto local, regional e nacional, o compromisso cívico e ético, imanente à sua missão de ensino, de produção de ciência e conhecimento e à formação de quadros com valia profissional e socialmente reconhecida.

A atividade da Universidade ficaria a ganhar se despertasse o interesse e contasse com o acompanhamento e o conselho avisado, empenhado, crítico, atuante e interventivo de parceiros externos, sejam eles pessoas ou instituições. As suas portas querem-se abertas aos pais dos jovens que a frequentam ou anseiam frequentar. Tais personalidades e entidades deveriam ser vistas como aliados e coadjuvantes na edificação e multiplicação da sua obra e do seu reconhecimento, avaliadores e certificadores da adequação dos fins e processos escolhidos, advogados e conselheiros dos caminhos e rumos seguidos, embaixadores e divulgadores da credibilidade das metas e realizações conseguidas.

3. Impõe-se exarar um balanço pontuado no tocante ao item que temos vindo a apreciar:

No caso da Universidade do Porto, digamo-lo por amor da verdade, o comportamento do seu primeiro Conselho Geral configura a exemplificação eloquente de um desastre, que urge ponderar. Os cooptados foram, em várias tomadas de decisão e na adoção de diversas medidas, correias de transmissão da ideologia do RJIES, voltaram deliberadamente as costas a necessidades vitais e a problemas cruciais da Universidade, deixaram-se instrumentalizar para a criação e agudização de conflitos e tensões, ignoraram ou desconsideraram as aspirações e o profundo pulsar e sentir da comunidade académica. 
Independentemente da respeitabilidade académica e pessoal dos seus membros, o Conselho Geral detém um poder deveras desproporcionado e questionável; carece de controlo, não responde perante qualquer instância e subtrai-se ao escrutínio dos seus eleitores.

Não é despicienda esta asserção: o método de eleição do Conselho, estabelecido no RJIES, assegura às Faculdades de maior dimensão mais possibilidades de ordenamento da Universidade, de lhe determinar a configuração, a orientação e o rumo, bem como de designar um Reitor com perfil ajustado ao serviço dessa agenda. Tudo quanto não pertence ao universo da engenharia, das biotecnologias, da medicina e economia é, em regra, uma carta fora do baralho. Nesta conformidade, deve ser definida uma quadratura legal que acolha a representação de todas as Faculdades no Conselho Geral.

\section{Conclusão: Necessidade de tocar os sinos a rebate}

A comunidade académica não pode curvar-se perante os druidas da escuridão. Tem que se sobressaltar, soerguer-se e rasgar a capitulação, desmascarar a farsa posta em cena, mobilizar-se sem descanso e extirpar do RJIES o quisto maligno do Conselho Geral, porquanto este órgão, com os poderes que lhe estão outorgados, ameaça os fundamentos e os fins supremos da Universidade. Tem que soltar um grito enérgico de protesto sobre o território da indiferença, do conformismo e do silêncio, levar até ao fim e às últimas consequências a sua pronúncia de indignação. De cabeça erguida e refrescada pela aragem suave e inebriante da dignidade e liberdade.

1. É urgente pôr termo ao evangelho do New Public Management, que levou a deslocar o poder da Universidade: das mãos dos docentes passou para os gestores e para os stakeholders. Em abençoada e santa aliança com a implantação de uma burocracia concebida para consumar fins ideológicos mais ou menos manifestos.

Gritemos e uivemos: A visão managerialista não pode sobreporse à visão académica, sob pena de se cair numa perversão! Não é do interesse da Universidade que ela e os académicos sejam dirigidos 
e geridos por 'missionários' de uma cartilha controlista e centralizadora, como se os primeiros fossem suspeitos e incompetentes para gerir a coisa universitária e os segundos estivessem dotados de uma competência sobrenatural para a dirigir, sem a conhecerem por dentro. Ora isto está a acontecer, nomeadamente através do Conselho Geral.

Mais, importa colocar a gestão ao serviço das funções académicas e não o inverso. E retornar ao basilar e fundamental, renovar e valorizar a qualidade da docência, terminar o discurso de desvalorização do ensino, das aulas magistrais e presenciais.

A gravidade da situação obriga a renovar e tornar bem audível o grito de Philip Altbach: It's the faculty, stupid!

Com este grito, Altbach pretendeu significar que nenhuma Universidade cumprirá, de modo elevado, a sua missão, sem pessoal académico bem qualificado, motivado e empenhado. Nenhum currículo, por mais inovador que se apresente, irá produzir bons resultados sem professores categorizados, com uma situação laboral estável e com salários decentes.

Lamentavelmente, o ensino superior a nível mundial tem concentrado os investimentos nos edifícios, laboratórios e similares, à custa do desinvestimento nas pessoas que fazem as instituições de referência e sucesso. Até os aduladores dos rankings incorrem nesse erro! Com efeito, para os rankings as instalações não são o filão de ouro mais importante de uma Universidade; são a notoriedade e produtividade dos académicos, o sucesso profissional dos seus estudantes.

Contudo, a avidez e a propensão para exibir números esquecem-se das pessoas, das suas legítimas aspirações, do seu bem-estar e dos seus direitos.

2. No passado, os académicos poderiam não ser bem pagos, mas desfrutavam de uma boa dose de autonomia, bem como eram donos do seu tempo; e tinham voz ativa na condução da Universidade. Este panorama tem vindo a mudar: o professorado perdeu a sua autonomia e é obrigado a fabricar e fornecer estatísticas e relatórios e a prestar contas, a toda a hora, dos passos dados e dos atos praticados, gastando nisso esforço, tempo e energias que tanta falta lhe fazem para a realização de coisas bem mais gratificantes. 
Vê-se submetido a deprimentes sistemas de avaliação e fiscalização, que se assemelham aos métodos de observação e vigilância do 'panóptico' usado por um Estado avaliativo, disciplinar, policial, prisional e punitivo. ${ }^{11}$

Há que encarar esta enorme perda portadora de consequências e implicações trágicas: a burocracia apoderou-se das universidades e estas deixam-se, pouco a pouco, enlear pelos braços controladores e tentaculares de entidades e forças externas. Também por esta via, a Universidade entrou na noite, sem saber quando começa o dia.

Tudo isto corrói o ethos e o conceito de comunidade académica, além de estreitar o seu espaço e liberdade de ação: o direito de participação na governação institucional, de escolher os respetivos protagonistas, tem sido restringido a passos largos. O poder dos professores diminuiu acentuadamente nesta conjuntura crepuscular.

Precisamente por isso, Altbach convida os académicos de todo o mundo a soltar o grito: It's the Faculty, stupid! Incita-os a sacudir o jugo e a recusar a aguilhada do império burocrático e do Conselho Geral (no tocante à eleição do Reitor e à sua preponderância na governança da Universidade), a reclamar uma carreira académica valorizada e a abertura de quadros de professores, capazes de atrair, estimular, manter e premiar jovens talentosos, condizentes com as exigências da missão universitária.

Este grito não visa trazer de volta os dias de autonomia irrestrita e deficiente avaliação do trabalho académico; mas reivindica formas de valoração consentâneas com os vetores axiais da função docente, rejeita categórica e liminarmente o aviltante ferro do policiamento, do aprisionamento e da sujeição a práticas de humilhação, punição e vexação. Almeja fundamentalmente renovar a admiração e a

11 O 'panóptico' é um modelo de arquitetura prisional, criado por Jeremy Bentham (1748-1832), filósofo e jurista inglês, que possibilitava a vigilância total sobre os presos por uma só pessoa e a partir de um único posto de observação. Michel Foucault (1926-1984) viu nele a fórmula, a inspiração e o paradigma da 'sociedade disciplinar' em que se transformou ou deseja transformar o governo liberal, melhor dizendo, neoliberal. O 'panoptismo', duramente exorcizado e repudiado por George Orwell (1903-1950), expressa o fito de reduzir o número dos que exercem o poder, ao mesmo tempo que multiplica o número daqueles sobre os quais é exercido. Corporiza o intuito de compensar a ausência e a destruição do Estado com a disseminação de mecanismos de disciplina e de controlo de tudo e todos e por toda a parte, destinados a 'vigiar e punir'. Digam-me que a Universidade não está a ser metida nessas varas! 
atração da vida académica e acordar os governantes, os fervorosos reformistas, as autoridades ditas (ou mascaradas) universitárias e os oráculos dos meios de comunicação social para o facto de que os docentes são o fuste e pilar central do ensino superior.

Desiludam-se os seus detratores, maledicentes e opositores: a desconsideração da centralidade e o descaso e menoscabo da dignidade e honorabilidade dos professores não elevarão a qualidade nem a produtividade da Universidade. O oposto é que é o verdadeiro: os docentes são a raiz do sucesso sem precedentes do ensino superior.

Como aconselhou Amanda Goodall com toda a propriedade, temos que libertar a Universidade da insensibilidade e da insanidade dos burocratas, contabilistas e gestores que se instalaram no seu comando e matam nos docentes os genes da dedicação, da motivação e paixão, da inovação e criatividade. ${ }^{12}$

No centro da agenda da Universidade, conclamou, não há muito tempo, Catharine Drew Gilpin Faust, Reitora da Universidade de Harvard, urge colocar as questões do ensino e da formação. E as que se relacionam com a reabilitação e dignificação da docência e dos professores.

Nesta conformidade, aqui fica a proclamação: É a Faculdade e não o Conselho Geral, estúpido! Ela requer adesão e renovação do nosso compromisso e empenho. Por favor, oiçam-na, ampliem-na e alistem-se no desafio e na campanha que ela propõe!

12 Amanda Goodall, Creative vs accounting, Times Higher Education, 22 de março de 2012. 